suggests that the cumulative effect of the genetic complex influencing the plant height is different in different varieties. Several workers observed the quantitative nature of this character, while monogenic, digenic and trigenic segregations were also reported in some crosses 2 .

Due to the influence of hybrid vigour and gene complexes on the expression of the plant hoights, the inheritance of this character in the present investigation has become very complicated. Further investigations are required to throw more light on this aspect.

I thank Prof. P. K. Sen, Department of Agriculture, University of Calcutta, for his holp.

\section{G. N. Mrtra}

Department of Agriculture, University of Calcutta.

1 Sen, P. K., and Mitra, G. N., Nature, 182, 119 (1958).

"Ramiah, K., Rice Breeding and Genetics (Ind, Coun, Agric. Res. Pub., 1953).

\section{VIROLOGY}

\section{A Rapid Method for Microanalytical Determination of the Amount of Tobacco Mosaic Virus in Plant Tissues}

THE development of the kinetic studies of virus biosynthesis requires an accurate and rapid method for determining the amount of virus nucleoprotein contained in small samples of tissue. Bancroft and Curtis $^{1}$ described a simple method which utilized trichloroacetic acid (TCA) as the substance for precipitating and extracting virus nucleic acid. Although this method is rather rapid, it results in the destruction of virus nucleoprotein and demands careful attention to the final concentration of TCA, because TCA itself has a high absorbance at $260 \mathrm{~m} \mu$ which may cause gross errors in the measurement of the small amount of viruses. The disadvantages of the method were overcome by using ammonium sulphate instead of TCA: the accuracy and rapidity of the method were also increased.

One to ten disks of tobacco leaves infected with the virus (9 mm. diam.) were homogenized with $6 \mathrm{ml}$. of distilled water. $5 \mathrm{ml}$. of the homogenate and $2 \mathrm{ml}$. of chloroform were mixed and shaken for $5 \mathrm{~min}$., cooled at $4^{\circ} \mathrm{C}$. for $15 \mathrm{~min}$. and then centrifuged at 3,000 r.p.m. for $15 \mathrm{~min}$. $4 \mathrm{ml}$. of the resultant supernatant wore transferred into a contrifuging tube, to which $1.33 \mathrm{ml}$. saturatod ammonjum sulphate was added $(0.25$ saturation) at room temperature. The mixture was thoroughly stirred until the precipitate produced had almost disappeared, and then allowed to stand for $10 \mathrm{~min}$., followed by $15 \mathrm{~min}$. centrifugation at 3,000 r.p.m. The resultant precipitate was dissolved in $4 \mathrm{ml}$. distilled water, stood for $10 \mathrm{~min}$, and centrifuged at 3,000 r.p.m. for 15 min. The optical density at $260 \mathrm{~m} \mu$ of the supernatant was measured using a spectrophotometer.

The absorption spectrum of the supernatant is shown in Fig. 1. The curvo was found to be approximately tho same as that of Reddi. It is clear from Fig. 2 that measurement of tobacco mosaic virus by this method is not disturbed by the presence of normal protein of host tissues. The infocted leaf tissues were homogenized with 20 times their wet woight of distilled water and the homogenate of healthy tissues was added. The virus concentration of these homogenates was determined by the present method. No. 6 on the abscissa in Fig. 2 shows the presence of infected

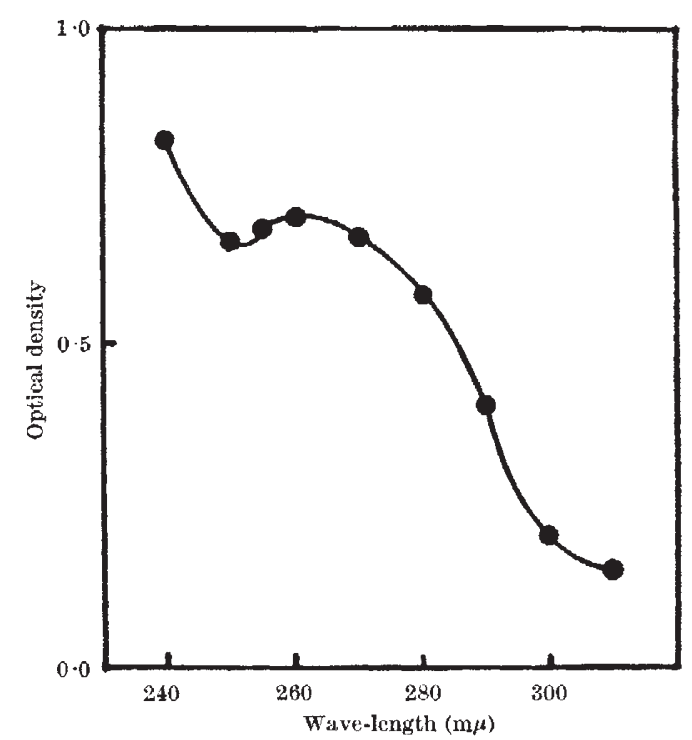

Fig. 1. Absorption spectrum of tobacco mosaio virus

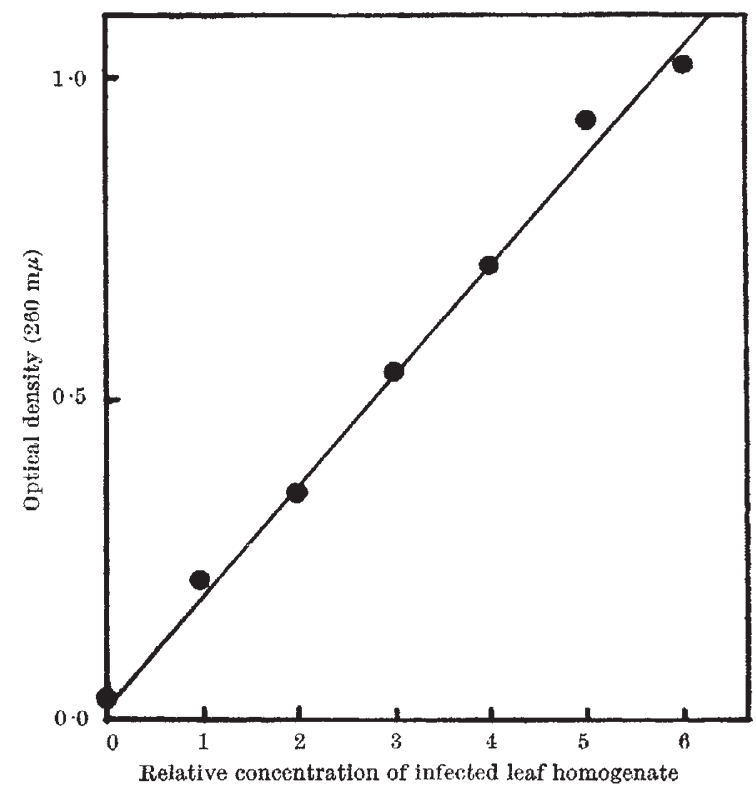

Fig. 2. Optical densities of the nucleoprotein obtained from infected leaf homogenates in the presence of healthy leaf homo-

homogenate only and No. 0 shows that of normal ones only. Nos. 1-5 represent the mixed homogenates containing $1 / 6-5 / 6$ of infected homogenate to total volume respectively. It was found that the optical densities of the nucleoprotein increased in a straight line according to the increase of the amount of infected homogenate in spite of the presence of healthy homogenate.

This method will be applied to the rapid determination of this virus in the very small quantity of samples.

Plant Pathology Laboratory,

$$
\text { Takeghr Taniguchr }
$$

Nagoya University, Anjyo, Japan.

'Bancroft, J. B., and Curtis, R. W., Phytopath., 47, 79 (1957).

${ }^{2}$ Reddi, K. K., Biochim. Biophys. Acta, 24, 238 (1957). 